\title{
Optimization of reinjection treatment technology for oilfield wastewater in Longdong area
}

\author{
Xiulan Zhu ${ }^{1, *}$, Yanlong $\mathrm{Ran}^{2}$, Wenjie $\mathrm{Guo}^{3}$, Ke Gai ${ }^{1}$, Yanju $\mathrm{Li}^{1}$, Caini $\mathrm{Yan}^{4}$, and Baobao Ding ${ }^{1}$ \\ ${ }^{1}$ Longdong University, College of Energy Engineering, Qingyang745000, China \\ ${ }^{2}$ Gansu Energy Group Company Limited, Qingyang745000, China \\ ${ }^{3}$ Second Petroleum Production Factory, Changqing Oilfield Company of PetroChina, Qingyang745000, China \\ ${ }^{4}$ Longdong University, School of Foreign Languages, Qingyang745000, China
}

\begin{abstract}
With the long-term water injection development of Longdong oilfields, most of the oilfield blocks have been fully in the mid-high water cut period, and the amount of oil production wastewater is increasing year by year. In order to prevent the waste of resources and energy of oil production sewage, the oil production sewage after reaching the standard is treated for reinjection, which will ensure the sustainable development of the oil field. Oil production wastewater contains crude oil, solid-phase suspended solids and other pollutants, with high salinity, and problems such as difficulty in oil-water separation, sludge, scaling and corrosion. The sewage treatment system uses a multifunctional water treatment device to effectively remove oil and filter through the "special microorganism + air flotation + filtration" process, and build a sludge sewage tank for sludge discharge and backwashing. The reformed oil recovery wastewater reinjection treatment technology turns "sewage" into "clear flow", reduces operating costs, improves wastewater treatment efficiency, and meets the water quality requirements of oilfield reinjection water.
\end{abstract}

\section{Introduction}

According to the " 2019-2025 China's Low-Permeability Oilfield Market Operation Situation and Strategic Consulting Research Report", it is pointed out that our country is rich in low-permeability oil and gas resources, and its reserves account for more than $2 / 3$ of the country's proven reserves, and its development potential is huge. Due to the characteristics of low permeability reservoirs with low permeability, low abundance and low single well productivity, such oilfields usually implement refined water injection work of "injecting water, injecting good water, and injecting enough water" to ensure stable and high production. The water injection quality of low-permeability oilfields is the main factor affecting the overall development effect of the oilfield.

Based on the research on the characteristics of domestic oilfield wastewater, this paper analyses the water quality characteristics of oil wastewater in Longdong area through indoor experiments and mine monitoring, and optimizes the oil wastewater treatment technology to achieve the quality of the treated water to meet the oilfield water injection development standards. The reinjection treatment of oilfield wastewater is of great significance to the green and sustainable development of oilfields and the protection of the ecological environment [1-3].

\section{Oilfield water injection source}

\subsection{Oilfield water injection source}

The types of water injected into the oil field are mainly divided into surface water, ground water, oil production sewage, sea water and mixed water. Surface water has low salinity and high content of sediment, dissolved oxygen, and organisms. Groundwater has high salinity and stable water volume, but it will cause waste of water resources. The sea is rich in water resources, high in oxygen and salt, and highly corrosive. The suspended solid particles also change with the seasons. With the extension of oil field mining time, most of its blocks have fully entered the middle and high water cut period and the production decline stage, and the output of oil production wastewater has also increased in the development of the mine oilfields. The compositions of oil production wastewater are very complex, with a high oil concentration, a large amount of suspended solids and other pollutants. It is a large-scale and wide-ranging source of pollution and causes waste of resources and energy. The amount of oil production wastewater is about $60 \% \sim 80 \%$, even as high as $90 \%$ in the late stage of oilfield exploitation.

Therefore, according to the requirements of water injection water source and water quality, as well as comprehensive consideration of water treatment, anticorrosion, and construction costs, the main source of oil field reinjection water is oil production wastewater.

2.2 Water quality characteristics of oil production wastewater

\footnotetext{
* Corresponding author: Xiulan Zhu, keaizhuk@126.com
} 
Oil production wastewater is a mixed water containing petroleum hydrocarbons, inorganic salt ions, sulfides, organic phenols, bacteria, solid particles, and chemical agents such as scale inhibitors, flocculants, corrosion inhibitors and fungicides added to the treatment station [4]. The nature of oil production wastewater not only depends on the lithology of the reservoir and the nature of the oil-water fluid, but also on the operating conditions of trans-oil dehydration [5]. According to the actual situation of the mine, oil production wastewater generally has the following characteristics:

(1) The water temperature of oil production wastewater is high, generally between $40 \sim 60{ }^{\circ} \mathrm{C}$.

(2) For oil production wastewater, the degree of salinity is high, it is usually between $2000 \sim 5000 \mathrm{mg} / \mathrm{L}$, and the highest degree of salinity can reach tens of thousands to hundreds of thousands of $\mathrm{mg} / \mathrm{L}$.

The main component of oil production wastewater is formation water, and formation water contains a large amount of metal salts formed by $\mathrm{Na}^{+} 、 \mathrm{~K}^{+} 、 \mathrm{Ca}^{2+} 、 \mathrm{Mg}^{2+}$, etc. For example, the salinity of produced water in Changqing Oilfield is usually around $50000 \mathrm{mg} / \mathrm{L}$. Scaling ions in the sewage will deposit under certain conditions and affect the effect of sewage treatment.

(3) The $\mathrm{pH}$ value of oil production wastewater is relatively high, generally between $7.5 \sim 8.5$.

(4) The crude oil content in oil production wastewater is high and generally $1000 \mathrm{mg} / \mathrm{L}$, and the high content can reach $2000 \sim 5000 \mathrm{mg} / \mathrm{L}$.

In the process of oilfield development, oil and water flow together through the reservoir, completion section sand control pipe, wellbore, wellhead, downhole and wellhead nozzles, valves, oil pipelines, etc. As the oilwater flow cross-section changes, they bear strong mechanical shear force, which makes part of the crude oil dispersed in the water. Due to different reservoir conditions and treatment methods, the oil content in sewage is usually tens to hundreds of $\mathrm{mg} / \mathrm{L} \mathrm{[6].} \mathrm{Crude}$ oil dispersion forms mainly include: dissolved oil (particle size $<1 \mathrm{~nm}$ ), emulsified oil (particle size 0.001 $\sim 10 \mu \mathrm{m})$, dispersed oil $(10 \sim 100 \mu \mathrm{m})$ and slick oil (particle size $>100 \mu \mathrm{m}$ ); among them, dissolved oil, emulsified oil, and dispersed oil and slick oil account for $0.2 \sim 0.5 \%, 10 \%$, and $90 \%$ of crude oil in sewage respectively. For slick oil, chemical agents can be added to remove (such as demulsifiers, etc.); for dissolved oil, it is more difficult to remove by physical or chemical methods.

(5) The composition of oil production wastewater is complex and heterogeneous.

In addition to the high oil content, it also contains other impurities, such as dissolved gas, suspended solids, and sediment. The dissolved gas includes strong oxidant $\mathrm{O}_{2}$, acid gas $\mathrm{H}_{2} \mathrm{~S}$ and $\mathrm{CO}_{2}$. The particle size range of sediment is generally between $0.05 \sim 100 \mu \mathrm{m}$, and the particle size ranges of clay, silt and fine sand are respectively 0.05 to $4 \mu \mathrm{m}, 4$ to $60 \mu \mathrm{m}$, and 60 to $100 \mu \mathrm{m}$. The bacteria content is high, which are usually sulfatereducing bacteria, saprophytic bacteria, iron bacteria, etc. Its content can be as high as $10^{6} / \mathrm{ml}$. The content of organic matter is high, such as microcrystals formed by colloidal asphaltenes, paraffin wax and volatile phenols.

(6) A certain amount of chemical additives such as flocculants remain in the oil production wastewater.

In summary, oil production wastewater has the characteristics of large volume, complex types, and difficult treatment. The use of oil production wastewater as the water source for oilfield water injection development has solved the problem of water resources and heat waste caused by oilfield oil production wastewater and reduced environmental pollution according to local conditions.

\section{Optimization of treatment technology for oil production wastewater}

\subsection{Analysis on the water quality of oil production wastewater in Longdong area}

According to the results of indoor experiments and onsite testing, the water quality characteristics of $\mathrm{CX} 4$ oil production wastewater in Longdong area are as follows:

(1) Various mineral salts in the formation are dissolved in the oil production wastewater, with a salinity of $6721.64 \mathrm{mg} / \mathrm{L}$, the water type is $\mathrm{NaHCO}_{3}$, and the water quality has a $\mathrm{pH}$ value of 8.75 , which is weakly alkaline. The cations are dominated by $\mathrm{Na}^{+}$and $\mathrm{K}^{+}$, and the content of $\mathrm{Cl}^{-}$and $\mathrm{HCO}_{3}{ }^{-}$is relatively high in oil production wastewater. So the mineralization of oil production wastewater is relatively high, and it has certain characteristics of scaling and corrosiveness.

(2) The oil content is $177.58 \mathrm{mg} / \mathrm{L}$, among which is mainly petroleum hydrocarbon polymer refractory organic matter [7].

(3) The suspended solids content is $92.7 \mathrm{mg} / \mathrm{L}$, and the median particle size of the suspended solids is 0.39 $\mu \mathrm{m}$.

(4) The total content of bacteria is $2 \times 10^{4} / \mathrm{mL}$, which is seriously exceeding the standard compared with the water quality index of reinjection water.

(5) In the process of crude oil gathering and transportation, chemical treatment agents are added, which has poor biodegradability.

\subsection{Optimization of treatment technology for oil production wastewater in Longdong area}

Clastic rock reservoirs have high requirements for water quality indicators such as suspended solids and oil in water injection, and each indicator needs to meet the standards of "SY/T 5329-2012 Clastic Rock Reservoir Water Injection Quality Recommended Indicators and Analysis Methods". Low-permeability oilfield reservoirs have the complex characteristics of small pores, fine throats, and weak seepage capacity. Therefore, when the water injection technology is used for mining, the water quality requirements are more stringent. High-quality water must be used for the reinjection of oil production wastewater in low-permeability oilfields, and the water 
quality of injection water must be refined to make the water quality up to the standard.

The treatment process for domestic oilfield wastewater is mainly divided into three steps of "oil separation-flotation-filtration". Its main purpose is to remove oil and filter solid suspended particles. With the continuous development of modern oil fields and the continuous increase in production and exploitation, there are still some problems in the treatment process of oil production wastewater [8-10]. The actual oil-water emulsification phenomenon is serious, and it is difficult for the tiny oil beads in the produced fluid to reaggregate, which makes the separation of crude oil from oil production wastewater more difficult. At present, the process and efficiency of oil production wastewater treatment needs to be improved. For the treatment of oily, suspended solids, fines and other indicators in the sewage, the commonly used treatment techniques for oil production sewage are shown in Table 1.

Table 1. Common treatment technologies for oil production wastewater.

\begin{tabular}{|c|c|}
\hline $\begin{array}{l}\text { Processing } \\
\text { technology }\end{array}$ & Main processing type \\
\hline $\begin{array}{l}\text { Oil removal } \\
\text { technology }\end{array}$ & $\begin{array}{l}\text { Gravity sedimentation separation technology, } \\
\text { pressure sedimentation degreasing technology, } \\
\text { ultrasonic degreasing technology, air flotation } \\
\text { degreasing technology, biological degreasing } \\
\text { technology, hydrocyclone degreasing } \\
\text { technology. }\end{array}$ \\
\hline $\begin{array}{l}\text { Filter } \\
\text { technology }\end{array}$ & $\begin{array}{l}\text { Microfiltration, ultrafiltration, nanofiltration and } \\
\text { reverse osmosis, electrodialysis and ion } \\
\text { exchange. }\end{array}$ \\
\hline \multirow{2}{*}{$\begin{array}{l}\text { Sterilization } \\
\text { technology }\end{array}$} & $\begin{array}{l}\text { Physical sterilization: high temperature, high } \\
\text { pressure, ultraviolet rays, electromagnetic } \\
\text { waves. }\end{array}$ \\
\hline & $\begin{array}{l}\text { Chemical sterilization: chlorine, peroxide, } \\
\text { aldehyde and other chemical agents. }\end{array}$ \\
\hline \multirow[t]{2}{*}{$\begin{array}{l}\text { Backwash } \\
\text { process }\end{array}$} & $\begin{array}{l}\text { Physical cleaning: composite casing scraper } \\
\text { cleaning, high-pressure water jet cleaning, pipe } \\
\text { cleaner cleaning, pneumatic cleaning, etc. }\end{array}$ \\
\hline & Chemical cleaning: chemical agents. \\
\hline $\begin{array}{l}\text { Mud } \\
\text { discharge } \\
\text { process }\end{array}$ & $\begin{array}{l}\text { Negative pressure mud removal process, } \\
\text { perforated pipe mud removal process, etc. }\end{array}$ \\
\hline
\end{tabular}

This article takes the analysis of the CX4 sewage treatment transfer water injection station of the Second Oil Production Plant of Changqing Oilfield as an example. The CX4 transferred water injection station has 5 upstream stations, the treatment layer is long 8 , the initial produced water treatment design scale is $600 \mathrm{~m}^{3} / \mathrm{d}$, and the produced water volume is $423 \mathrm{~m}^{3} / \mathrm{d}$. The design scale of reinjection water injection is $2000 \mathrm{~m}^{3} / \mathrm{d}$, and the clean water-sewage split injection process is adopted, that is, the clean water volume is $1400 \mathrm{~m}^{3} / \mathrm{d}$, and the produced water volume is $600 \mathrm{~m}^{3} / \mathrm{d}$ after the designed treatment reaching the standard. At present, the total daily liquid production of 5 upstream station warehouses in CX4 transferred water injection station is $1100 \mathrm{~m}^{3}$, the average water content reaches $48 \%$, and the daily water production is $530 \mathrm{~m}^{3}$. In the initial stage, the sewage treatment process was simple, and the water quality of the oil field produced water exceeded the standard, which could not meet the water injection demand and seriously affected the development and production of the oil field. Moreover, the addition of chemicals before the sedimentation deoiling tank caused high operating costs and difficult treatment of coagulated sludge. The sewage and sludge tank has a volume of $192 \mathrm{~m}^{3}$, of which the sludge tank volume is $64 \mathrm{~m}^{3}$. The volume is small, which makes it impossible to meet the sedimentation of the sludge discharge from the degreasing tank and the backwash water volume of the filter. It has a bottom seepage structure, where sludge accumulates in the sewage pond, resulting in secondary pollution of the oil removal tank, and the operation effect of the multifunctional device is poor after being put into operation. $1 \# 300 \mathrm{~m}^{3}$ oil removal tank is equipped with negative pressure sludge discharge device, $2 \# 300 \mathrm{~m}^{3}$ oil removal tank is not equipped, and the drainage pump is not equipped, so the effect of gravity sludge discharge is poor.

The process of oil production wastewater treatment after transformation is shown in Figure 1. The multifunctional water treatment device in Figure 1 adopts the process of "special microorganisms + air flotation + filtration", and uses principles such as "Beijiaqing" efficiently combine bacteria to degrade organic matter and oil (reducing sludge), centripetal air flotation and degreasing, and micro-vortex Rotary decontamination and turbidity reduction, filtration purification, electrical scale control and descaling, electrical sterilization, dissolved oxygen desulfurization, electrical corrosion inhibition and deoxidation, filter material vortex rewashing, etc. The quality of the treated oil production wastewater is fully up to standard.

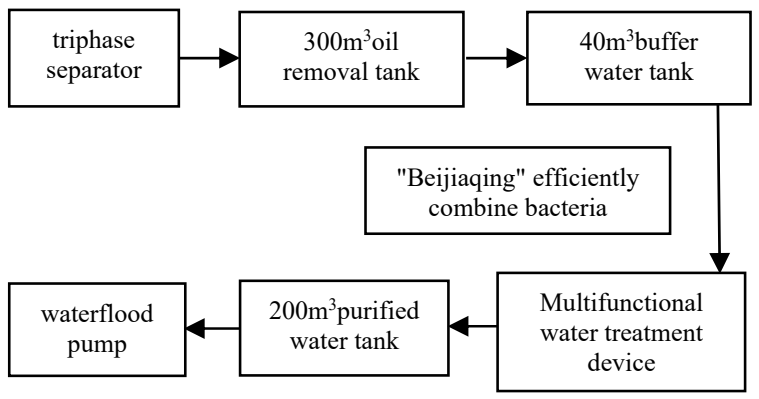

Fig. 1. CX4 conversion produced water treatment process (after transformation).

Aiming at the problems of small sludge and sewage pond in the station and secondary pollution caused by sewage to the operation of water treatment equipment, it is proposed to build a $230 \mathrm{~m}^{3}$ sewage sludge pond at the well site outside the station, of which the sludge pond $150 \mathrm{~m}^{3}(8 \times 7.5 \times 2.5 \mathrm{~m})$, sewage Pool $80 \mathrm{~m}^{3}(8 \times 2.5 \times$ $4 \mathrm{~m})$, used for sedimentation and degreasing tank sludge and multi-function treatment device backwash. At this 
time, the treatment and reinjection of the oil production wastewater not only reduces operating costs, but also improves wastewater treatment efficiency, energy conservation and environmental protection.

\subsection{Impact of water injection quality on oilfield development}

After long-term operation of oilfield sewage treatment equipment, its operational stability deteriorates, and the problems of sludge deposition and scaling inside the equipment are serious. These problems lead to the deterioration of the environment in the reinjection water treatment system and greatly affect the quality of the reinjection water in the oilfield. In particular, the mineral salt ions, oils and suspended solids in the oil production wastewater after reinjection treatment have a relatively large impact on the development of oilfield water injection. The reinjection water with high mineral salt ion concentration has poor adaptability after being mixed with formation water, and the tendency of scaling in pipelines and equipment is obviously enhanced. Blockage of water injection wells is prone to occur, and the fouling of pipeline and equipment has a serious impact on the overall water quality. After the emulsified oil droplets entered the oil layer, the liquid resistance effect is easy to occur, which reduces the fluid seepage ability. Suspended substances in oil production wastewater such as microorganisms, chemical precipitation, clay and related organic matter, etc. when they enter the oil layer, they will block the oil layer pores [11] and even corrode pipelines and equipment. It is necessary to do a good job of cleaning, sludge discharge, and water quality testing regularly to achieve the purpose of improving the effect of water quality treatment.

\section{Conclusion}

(1) Considering the requirements of water injection source and water quality, water treatment, anti-corrosion, cost and other aspects, oil production wastewater is the best source of oilfield reinjection water. The reinjection of oil production wastewater is conducive to saving water resources, reducing environmental pollution, replenishing formation energy, and improving the ultimate oil recovery rate.

(2) The content of $\mathrm{Cl}^{-}, \mathrm{HCO}_{3}{ }^{-}$and bacteria in the oilfield wastewater in Longdong area is relatively high. The problems of sludge, pipe scale and corrosiveness in the process of oilfield wastewater treatment are serious, and it is easy to cause reservoir blockage.

(3) The oilfield wastewater treatment system in Longdong area includes a multifunctional water treatment device, which uses the "special microorganism + air flotation + filtration" process to effectively remove oil and filter. At the same time, sludge and sewage tanks will be built to be used for sludge discharge and backwashing of degreasing sedimentation tanks and filter devices to improve sewage treatment efficiency and ensure that the water quality meets the oilfield reinjection standard.

\section{Acknowledgements}

This research was financially supported by Gansu Provincial Industrial Green Low-Carbon Transformation and Upgrading Project (Project Nos. GGLD-2019-060), 2020 Gansu Provincial Association for Science and Technology Innovation Driven Engineering Demonstration Project (Project Nos. ZLGC202003-4), Longdong University Youth Science and Innovation Fund Project (Project Nos. XYZK1906) and Longdong University Education and Teaching Research Project (Project Nos. 2019-42).

\section{References}

1. Yang $\mathrm{Z} H$, Analysis of the problems and countermeasures of water injection quality in lowpermeability oilfield water injection development, Chem Manage, 1(2019)

2. Xie Z, Cao J K, Xiang Z Y. Evaluation for Operation Efficiency of Waste Water Treating Process Used by Changqing Oilfield, Chem Ind, 27(2009)

3. Ding H. New technology research of waste water reinjection treatment and resource utilization in Shengli oilfield, Environ Prot Oil gas fields, 22(2012)

4. Zhang Z H, Feng J X, Zheng T L et al, Pretreatment of oilfield production wastewater using Coagulation/ microbubble air flotation technology, Technol Water Treat, 40(2014)

5. Fan H F, Ma J, Application of ionic liquids in oilfield wastewater treatment, J Fuel Chem Technol, 39(2011)

6. Zhu L N, Research on deteriorating factors and treatment technology of oilfield injection water quality, Dissertation, Northeast Shiyou Univ, 2013

7. Huang K, Research and application of magnetic loading precipitation-magnetic filtration treatment in oil extraction wastewater, Environ Eng, 37(2019)

8. Li P Y, Cheng P, Yan H B et al, Study on Reinjection Treatment Technology of Produced Water in Mobei Oilfield, Mod Chem Res, 12(2019)

9. Liu T, Zeng S P, Chen P X, Research on damage evaluation of sewage reinjection in extra low permeability reservoir, J Chongqing Univ Sci Technol (Nat Sci Ed), 21(2019)

10. Kalantariasl Azim, Schulze Kai, Storz Jöerg et al, Produced Water Re-Injection and Disposal in Low Permeable Reservoirs, J Energy Resour Technol, 21(2019)

11. Li S L, Wang L C,Wang G L, Analysis and application of oil production wastewater reinjection technology, Chem Eng Equip, 7(2019) 